\title{
Analysis of the Influence of Risk Management And Profitability of Companies At Companies Listed on The Indonesia Stock Exchange Year 2014-2016 With Hedging Strategies As Mediating Variable
}

\author{
Andi Farouq \\ University doctoral student, 17 Agustus 1945 Surabaya, Indonesia \\ Tri Ratnawati \\ University lecturer, 17 Agustus 1945 Surabaya, Indonesia \\ Sunu Priyawan \\ University lecturer, 17 Agustus 1945 Surabaya, Indonesia
}

\begin{abstract}
The business world is increasingly advanced and supported by increasingly sophisticated technologies and information systems, brought the impact of increasingly intense competition among the businessmen. Even this will be increasingly tight competition after entering the era of liberalisation of world trade market, because besides is an opportunity for the company-company in Indonesia to enter the international market, it has also led to a flood of products and services from abroad to the domestic market. Therefore, to deal with the increasingly strict business competition, the management companies are expected to be able to work more efficiently and effectively. Any wisdom taken should be able to provide optimal results for the company so that the company is still able to compete with other companies. The hypothesis of the research is H1: Risk management strategy significantly to influential hedge on companies listed on the Indonesia stock exchange Years 2014-2016, H2: Influential profitability significantly to hedging strategies in companies listed on the Indonesia stock exchange Year 2014 - 2016, H3: influential hedge Strategy significantly to value the company at companies listed on the stock exchange The effect of Indonesia Years 2014-2016. The population in the research this is on the Indonesia stock exchange Year 2014 - 2016. Method of data processing is using SEM (Equational Structure Modeling) with AMOS version 18. The result of hypotheses shows of the variable risk management hedging strategy based on the indicators-charge indicators will show significant results with a value of $C R 3,285$. This value is greater than 1.96 . Besides significance levels obtained $0.001(p<0.05)$. The results of the estimation of parameters of the variable profitability against hedging strategies based on the indicators-charge indicators will show significant results with a value of CR 6.633. This value is greater than 1.96. Besides significance levels obtained $0.000(p<0.05)$. The calculation result shows the value of the CR 0,383 and the significant value of 0,702 ( $p>$ 0.05). This means that the results of the hedging strategy is not a positive and significant effect against the value of the company.
\end{abstract}

Keywords: Risk management, hedging strategy, and value of the company

\section{INTRODUCTION}

The company can compete in the global market is largely determined by the performance of the company itself. Companies that have high competitiveness indicated the company should have good performance. The company is not able to maintain its performance will gradually ousted from the environment industry. Therefore the survival of companies maintained then the management must be able to maintain and increase its performance. With respect to the 
improved performance of the company, the management will always be faced with decision making.

The financial report is a means of communication for the management and external parties to know the financial condition and business continuity company. Analysis of financial reports are used to help address gaps in that information. An analysis of the financial statements of an enterprise is basically done for want of knowing the level of profit, the level of risk or the level of health of a company. The application of risk management can also help companies devise strategies to achieve the goals of the company having regard to the balance of the interest of all stakeholders, as well as policy and protect the resources that belong to the company.

Companies that successfully implementing effective risk management has a long-term competitive advantage that can keep the stakeholders get their respective rights, because of the risk management system is designed properly will ensure that all activity containing the risk carefully evaluated by managers and workers who were responsible (Nocco and Stulz, 2006). Susilo and Kaho (2010), by applying risk management would be better in controlling risk, companies can better explore and exploit opportunities, improve relationships with stakeholders, can increase the reputation of the company and also protect directors and other officials in managing the company.

The value of the company may be determined by profitability. Profitability is the ability of the company gained profit. The company earned profit derived from the sale of the investments made and the decision of the company. Profitability is also a description of performance management in managing the company. High profitability shows the prospects of a good company so that investors will respond positively and the share price will rise. High profitability will provide profits to investors. This has been the attraction of investors to own shares of the company. (Ade, 2015). Investors will choose to invest in companies that have a score ratings criteria are included in the category of trust. Through the implementation of Good Corporate Governance will produce a good performance.

\section{Risk management}

\section{LITERATURE REVIEW}

According to Djohanputro (2008:43), risk management is the process of structured and systematic in identifying, measuring, mapping, develop alternative handling of risks, and monitor and control the handling of risk. According to Marthin and Bonny (2014), risk management is a structured approach in managing uncertainty relating to the threat; a series of human activity including: risk assessment, development of a strategy to manage it and risk mitigation by using empowerment/resource management.

Strategies that can be taken include moving the risk to another party, avoiding the risk, reducing the negative effect of the risk, and accommodate some or all of the consequences of a particular risk. Traditional risk management focuses on risks incurred by physical or legal causes (such as natural disasters or fires, death, and lawsuits. Financial risk management, on the other hand, focuses on risks that can be managed by using financial instruments. Risk management involves the processes, methods and techniques that assist project managers maximum probability and consequence of positive and minimum event probability and consequences of the event. The process undertaken in the management of risk is (Marthin and Bonny, 2014):

1. Risk Management Planning, planning involves deciding how to approach and planned risk management activities for the project. 
2. identification of risk, the next stages of the process of identifying risks is to identify the types of risks that may be (and generally are) faced by every business person.

3. Qualitative risk analysis, qualitative analysis in risk management is the process of assessing the (assessment) the impact and likelihood of risks already identified. This process is done by arranging the risk based on the effect on the goals of the project.

4. Quantitative risk analysis is the process of identification in numeric probability of any risks and consequences against the purpose of the project.

5. Risk Response Planning, Risk response planning is a process that is done to minimize the level of risk facing up to an acceptable limit.

6. Control and Monitoring of risks, this step is the process of supervising the risks that had already been identified, the remaining risks, monitor and identify new risks, ensuring the implementation of the risk management plan and evaluate their effectiveness in reducing the risks.

\section{Profitability}

Profitability is the ability of the company in generating profits or the ability of the various resources used in operating activities (David and Wilopo, 2011). The profitability of the company is the level of net profit gained by the company that is capable of at the time of running operations (Nurhayati, 2013). According to Weston and Copeland (1997) the profitability is the extent to which the company generates profit from sales and investment company. Brigham and Houston (2011) define the profitability is the end result of a number of policies and decision management company (Ade, 2015). According to Brigham and Houston (2001), profitability is a series of policies and decisions.

Profitability can be described as the ability of the company in generating net income from activities performed on the accounting period. According to Saidi (2004) Profitability was the company's ability to obtain profit. Investors infuse the stock in the company is to get the return, consisting of yield and capital gains. The higher the ability earn a profit, then the greater the expected return of investors, making the value of the company for the better. The company's survival is influenced by many things, among others, the profitability of the company itself. Profitability is one of the factors for assessing both the bad performance of the company.

Return On Assets (ROA) is a ratio of profitability that is used to measure the effectiveness of the company in generating profits by leveraging the total assets. As for factors that can affect the profitability of a company including Current Ratio (CR), Total Asset Turnover (TATO), Debt To Equity Ratio (DER), Debt Ratio (DR), Sales growth and the size of the company. The ratio of Profitability according to the Hanafi and Mamduh. Halim (2005) is a ratio that measures the ability of a company making a profit (profitability) at the level of sales, assets and capital stock. In general the company's profitability ratio can be measured by using some other ratio between the Return on assets, and Return on Equity (David and Wilopo, 2011).

\section{Hedging strategies}

Hedging strategies according to Madura (2000:275) strategy of hedging are actions taken to protect a company from exposure against the exchange rate. Exposure against fluctuations in exchange rates was the extent to which a company can be affected by exchange rate fluctuations. Hedging strategies will ensure that the value of foreign currency used to pay (outflow) or an amount of foreign currency that will be accepted (inflow) on the foreseeable future will not be affected by changes in foreign exchange rate fluctuations (Faisal, 2001). Hedging strategy policy rationality based on two mainstream theory, each providing a different runway. 
Multinational companies facing foreign exchange exposure which is highly significant because it delays the completion of their trade transactions. Such exposure caused by the time between the time of approval of the price and delivery of the goods, as well as by the dominant settlement prices in foreign currencies. In addition, multinational companies also run the risk of exchange rate fluctuations and that leads to uncertainty of the value of the company (Faisal, 2001).

The greatest risk of multinational transactions brought about by fluctuations in foreign exchange rates. Fluctuations in foreign currency exchange rates have a direct impact on turnover, product pricing, as well as the level of profit of the importers and exporters. Fluctuations in foreign exchange rates also contributed to the uncertainty of the value of assets and liabilities, as well as threatening the survival of the company (Levi, 1996). According to an analysis of the capital structure of the Modigliani-Miller $(1958,1963)$, policy strategies of hedging does not provide any added value. In a perfect capital market, each of the shareholders can manage their own portfolio strategy in accordance with the risk profile of their wills. However such assessment, the company operating on the capital market are not perfect, and market imperfections using risk management to explain the motivation of the policy strategy of hedging Suriawinata, 2004).

Davies et al. (2006) concluded that companies in Norway implemented a policy of hedging strategy is not for the purpose of alleviating the financial distress cost and access to external capital markets. His findings are that the size of companies, internationalization, and the liquidity effect on the policy of hedging strategies.

Klimczak (2008) contributed in the theory of risk management with comprehensive research over theories hedging strategies. His findings stated that the policy of hedging strategy in Poland is not based on one of the fundamental theories. However, foreign exchange exposure influenced, market-to-book value, the sector of information technology and services, as well as the size of the company.

\section{The value of the company}

Rica and Islahudin (2008:7) is defined as the market value. The value of the company can deliver prosperity in maximum shareholder when the company's share price increases. The higher the stock price, then the higher prosperity shareholders. To achieve the company's value is generally the financier surrendered the management to the professionals. Professionals are positioned as Manager or Commissioner.

The value of the company is certain conditions that have been achieved by a company as an overview of the beliefs of the society against the company after going through a process of activities over the past few years, namely since the company was founded up to this time. According to Husnan (2013) the value of the company or also called the company's market value is the price payable by prospective buyers if the company were sold.

According to Brigham Ghapenski (1996) in Darminto (2010), management in managing assets efficiently in an effort to improve financial performance as well as the value of the company. One of the fundamental duties of the managers increase or maximize company value (the value of the firm). The value of a company showing the value of the assets owned by the company, including securities that have been rendered. 
In research conducted by Wijaya and authority (2010), the company's value can be calculated using the Price to Book Value (PBV). Market value differs from the book value. If the book value is the price recorded on the company's stock value, then the market value is the price a stock that occurs in a particular stock market formed by the demand and supply of the shares by the market participants.

The ratio of market value to give management an indication of what investors think about past performance and future prospects of the company (Nurhayati, 2013). The market price of the shares of the companies that formed between buyers and sellers of at the time of transaction occurs is called the market value of the company, because the market price of the stock is considered a reflection of the real company asset value.

The value of the company formed through the indicator value of the stock market was heavily influenced by investment opportunities. A firm is said to have good value if the company's performance is also good. Corporate values can be reflected in its stock price. If the value of their shares could be said high value his company is also good. Because the main purpose of the company is to increase prosperity through increased value of the company owners or shareholders. Ratio-financial ratio used to find out the market value of the company.

\section{Draft Writing}

\section{RESEARCH METHOD}

The population in this study is that companies that are listed in the LQ 45 issuers on the Indonesia stock exchange in the period the year 2012 - 2016 a number of 45 companies. Election 2012 period up to 2016 as a period of research is based upon 2 considerations, namely: (1) that the period presents data last published by the Indonesian Capital Market Directory (ICMD), (2) that the period having gone through a period of economic crisis, thus assuming the economic conditions already back to normal.

First year research activity begins with data collection conducted through two techniques namely (a) Library study and (b) Field study consisting of observation, interview and questionnaire. Literature study is done by studying the books, literature, scientific writing, where researchers seek theoretical data as a comparison material by applying it to the problem under study. Field study aims to observe the object of research so as to understand the actual conditions. Interview is a technique of collecting data in the form of verbal communication with related parties. Data are analyzed through the following stages: (a) data processing; (b) Evaluation and Analysis of Results; (c) conclusions; and (d) develop financial literacy and financial inclusion models and strategies in the first year of research.

\section{Technique Analysis}

Data processing technique used is using factor analysis used to determine the dominant factors in explaining a problem. This analysis can be viewed as an extension of major component analysis which is basically aimed at obtaining a small number of factors that have the following properties:

1. Be able to explain as much as possible the diversity of data

2. These factors are mutually free

3. Each factor can be interpreted

Factor analysis was processed by SPSS to get factor (dominant indicator) from each research variable that is risk management, profitability, hedging strategy and corporate values. This research uses of data analysis in SEM (Equational Structure Modeling) using the AMOS version 18 (Ferdinand, 2000:6). 


\section{RESULTS AND DISCUSSION}

Results analysis using SEM research model shown in Figure 1. A model is said to be good in the development of the conceptual and theoretical hypothesis supported by empirical data, structural equation model test results are shown on the following picture:

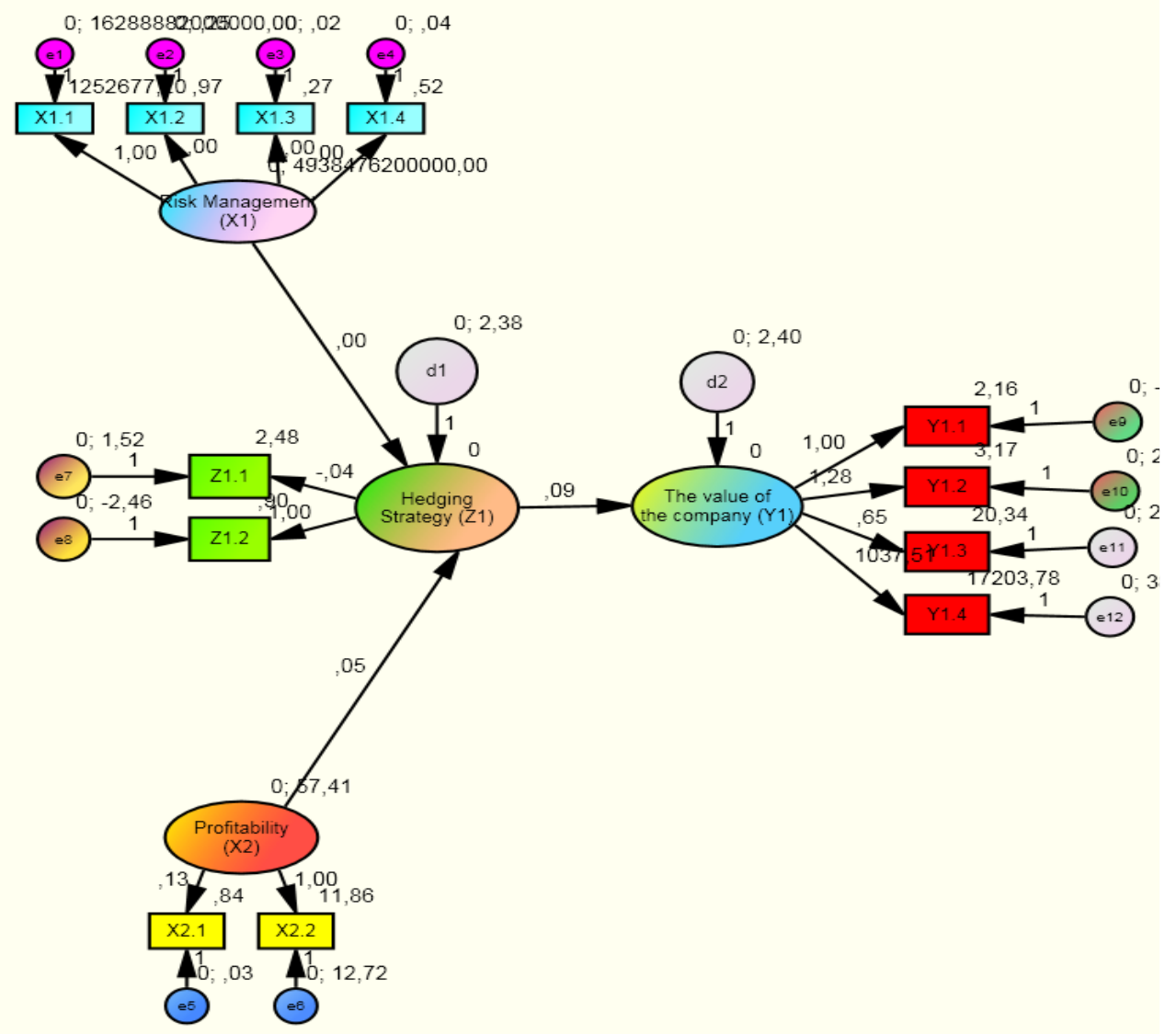

Figure 1. Structural Equation model

The table below is a table of the results of tests of Goodness of Fit of the model taken from the last modified or the results of the development model of the best mods. The results of calculation of index of conformity (goodness of fit index) show that of the eight criteria are evaluated it turns out only two criteria that already meet (fit) i.e. the Goodness of Index (GFI) and RMR. 
Table 1. Index of Suitability Model In Structural Models

\begin{tabular}{|l|c|c|c|}
\hline \multicolumn{1}{|c|}{ Goodness of Fit Measure } & Indeks & Cut off & Description \\
\hline Chi-square of estimate model & 89,055 & & \\
\hline Probability Level & 0,000 & $>0,05$ & Fit model \\
\hline Goodness of Index (GFI) & 0,918 & $\geq 0,9$ & Fit model \\
\hline Adjusted Goodness of Index (AGFI) & 0,855 & $\geq 0,9$ & No fit model \\
\hline RMSEA & 0,050 & $\leq 0,08$ & Fit model \\
\hline RMR & 0,042 & $\leq 0,05$ & Fit model \\
\hline Tucker-Lewis Index (TLI) & 0,905 & $\geq 0,9$ & Fit model \\
\hline Comparative Fit Index (CFI) & 0,915 & $\geq 0,9$ & Fit model \\
\hline
\end{tabular}

Testing the hypothesis presented in this study was done based on the value of the Critical ratio of CR from a relationship of causality. The results of the analysis of the relationship of causality between the variables research using program AMOS version 6 can be seen in table 2 .

Table 2. Test Causality Regression Weight

\begin{tabular}{|c|c|c|c|c|c|c|}
\hline \multicolumn{2}{|c|}{ The Relationship Of Causality } & Std. Est. & SE & CR & Significant \\
\hline Risk management & $\rightarrow$ & $\begin{array}{c}\text { Hedging } \\
\text { strategies }\end{array}$ &, 000 &, 000 & $\begin{array}{c}- \\
3,285\end{array}$ &, 001 \\
\hline Profitability & $\rightarrow$ & $\begin{array}{c}\text { Hedging } \\
\text { strategies }\end{array}$ &, 052 &, 008 & 6,633 &, 000 \\
\hline Hedging strategies & $\rightarrow$ & $\begin{array}{c}\text { the value of the } \\
\text { company }\end{array}$ &, 093 &, 243 & 0,383 &, 702 \\
\hline
\end{tabular}

\section{The influence of risk management against the strategy of Hedging}

Hypothesis 1 stated that influential positive risk management and hedging strategy significantly to. The results of the estimation of parameters of the variable risk management hedging strategy based on the indicators-charge indicators will show significant results with a value of CR 3,285. This value is greater than 1.96. Besides significance levels obtained 0.001 (p $<0.05$ ). So, based on statistically testing risk management variable is negative and significant effect against the value of the company. So it can be concluded that the first hypothesis is acceptable. The results of this study provide empirical understanding for management of risk management that tends to raise the value of the company. This condition describes the less note this factor by the perpetrators of the Exchange, because economic growth more describe future expectations of return. Therefore in the short term economic growth does not affect the value of the company.

\section{The influence of profitability against the strategy of Hedging}

The results of the estimation of parameters of the variable profitability against hedging strategies based on the indicators-charge indicators will show significant results with a value of CR 6.633. This value is greater than 1.96. Besides significance levels obtained 0.000 ( $\mathrm{p}<$ 0.05). So the second hypothesis States the profitability of influential hedge strategy significantly to proven truth. The results of the test showed that there was significant influence between the hedging strategy against profitability. The results of this study in accordance with the results of previous estimates and in line with economic theory of argumentation that the level of profitability will be able to improve the company's ability to protect the value of the company.

The results of this study provide empirical understanding for management that increases 
economic growth tends to degrade the performance of the company, although the decline was not statistically significant. This condition is caused due to economic growth is the hope of the future, so that in the short term does not affect the performance of the company. Management generally viewed economic growth as a long-term prospect, so that the impact of the new economic growth can be felt in the future.

\title{
The influence of hedging strategies against the value of the company
}

Hypothesis 3 stated that the hedging strategy is not positive and influential value company. The higher the ability of foreign currency expenditure control a company, the higher the value of the company. The calculation result shows the value of the CR 0,383 and the significant value of 0,702 ( $p>0.05$ ). This means that the results of the hedging strategy is not a positive and significant effect against the value of the company.

The test results are statistically, financial leverage and significant negative effect on the level of significant less than $1 \%$ (th $=-19.335$; with the value of the sig-t $=0.000$ ) of good corporate governance. So, based on the test results are statistically the financial leverage effect negatively and significantly to the company's performance. The results of this study provide empirical understanding for management that the proper hedging policy, then the company will have a strong competitiveness that is reflected in the good corporate governance system. The findings of this research is that the use of debt for the company resulted in a decrease in ROA. This condition is caused due to the use of debt has not resulted in a maximum rate of return lower than the cost of the flowers. The average return (ROA) produced $2.75 \%$ is still lower than the cost of flowers, namely of $6.88 \%$.

\section{SUMMARY}

1. Significant effect against risk management hedging strategies in companies listed on the Indonesia stock exchange Years 2014-2016.

2. Profitability effect significantly to hedging Strategies in companies listed on the Indonesia stock exchange Years 2014-2016.

3. Hedging Strategy has no effect on the value of the company significantly to companies listed on the Indonesia stock exchange Years 2014-2016.

\section{LIMITATIONS}

1. The amount of this research period of only three years, it's grown to a 5 year research period.

2. The number of the sample in this research less upgrades.

\section{BIBLIOGRAPHY}

\author{
Abdullah, Faisal, 2001. Basics of financial management. First Edition,. First printing, Malang Muhammadiyah \\ University of Malang \\ Ade Winda Septia, 2015, Influence Profitability, investment decision, the decision of funding, and the dividend \\ policy of the company on the manufacturing companies listed on the Indonesia stock exchange.
}

Bramantyo. D., 2006. Integrated Corporate risk management, PPM Darminto Publishers, 2010. The influence of external factors and the various financial decisions against the value of the company. Application Management Journal, vol. 8 No.3

Bramantyo, D. 2006. Integrated Corporate Risk Management. Publisher PPM, Jakarta.

David Tjondro dan R. Wilopo, 2011. The Influence Of Good Corporate Governance (Gcg) Against The Profitability And Performance Of The Banking Company's Stock Listed On The Indonesia Stock Exchange Journal of Business and Banking. Volume 1, No. 1, May 2011, pages 1 - 14. STIE Perbanas Surabaya. 
Ferdinand, A. 2000. Structural Education Modelling in research management. The first edition. Semarang: Diponegoro University.

Klimczak, Karol Marek. 2008. Corporate Hedging and Risk Management Theory. The Journal of Risk Finance. Vol 9 No 1 (20-39).

Levi, Maurice d. 1996. International financial framework. Yogyakarta: Andi Offset

Madura, Jeff, 2001, Introduction to business, the first edition of Salemba, Jakarta: four.

Marthin D. J. Sumajouw, dan Bonny F. Sompie, 2014, Risk management in Implementing Construction services company in Papua Province, a scientific journal Media Engineering Vol.4 No.2, September 2014 (109-118) ISSN: 2087-9334, Universitas Sam Ratulangi.

Nurlela, Rika dan Islahuddin. 2008. Influence of Corporate Social Responsibility Of the company's Managerial Ownership Percentage as Moderating Variables. SNA XI Pontianak

Suad Husnan and Eny Pudjiastuti, Fundamentals of financial management, 5th Edition, UPP STIM YKPN in Yogyakarta, 2006.

Suriawinata, faith, 2004, the study of the behavior of the company's Hedging foreign exchange Derivative Instruments With, dissertation, 1993, 2004 